\title{
UPAYA PENINGKATAN KESADARAN, KEWASPADAAN DAN \\ KESIAPSIAGAAN DALAM MENGHADAPAI BENCANA OLEH BADAN PENANGGULANGAN BENCANA DAERAH KABUPATEN SUMENEP
}

\author{
Enza Resdiana ${ }^{1}$ \\ Dosen Prodi Ilmu Administrasi Publik \\ Email: enza.resdiana@gmail.com \\ Nur Inna Alfiyah ${ }^{2}$ \\ Dosen Prodi Ilmu Administrasi Publik \\ Email: fifi.alfiyah@yahoo.com
}

\begin{abstract}
ABSTRAK
Indonesia merupakan negeri yang memiliki karateristik geografis rawan bencana. Terletak di wilayah cincin api dunia, Indonesia sangat rawan diguncang gempa bumi hingga gelombang tsunami. Gunung-gunung berapi yang terdapat di hampir semua pulau juga menambah rentetan kemungkinan terjadinya bencana vulkanologi. Posisinya yang berada di atas garis khatulistiwa membuat Indonesia hanya memiliki dua musim, yakni panas dan penghujan. Penelitian ini menggunakan metode kualitatif deskriptif, yang menjadi subyek dan obyek dalam penelitian ini adalah Badan Penanggulangan Bencana Daerah Sehingga tujuan dari penelitian ini adalah untuk mengetahui pentingnya upaya peningkatan kesadaran, kewaspadaan dan kesiapsiagaan dalam menghadapai bencana (Studi di Badan Penanggulangan Bencana Daerah Kabupaten Sumenep). Upaya peningkatan kesadaran, kewaspadaan dan kesiapsiagaan yang dilakukan oleh BPBD terhadap DESTANA (Desa Tangguh Bencana) telah berupaya untuk meningkatkan kesadaran dan keterampilan masyarakat dalam bentuk sosialisasi dan pelatihan secara berkelanjutan dengan melakukan berbagai pelatihan simulasi penyelamatan sedangkan Situasi bencana yang terjadi diluar cakupan DESTANA, BPBD telah memberikan pelayanan dalam penyelamatan bencana dengan pemberian anggaran terhadap korban. Partisipasi dan pola pikir masyarakat masih rendah sehingga sosialisasi dan pelatihan yang dilakukan merupakan faktor pemhambat dalam meningkatkan kesadaran masyarakat
\end{abstract}

Kata Kunci: Bencana, Upaya peningkatan dan Partisipasi 
PENDAHULUAN

Badan penanggulangan Bencana Daerah (BPBD) Kabupaten Sumenep sebagai badan penanggulangan bencana di daerah turut serta dalam menangani bencana daerah sebagai tanggung jawab terhadap Badan Nasional Penanggulangan Bencana (BNPB) memiliki peran penting dalam meminimalisir terjadinya korban bencana bencana sebagaimana yang tertera dalam undang-undang yang ada sehingga perlu melakukan serangkaian kegiatan untuk mengantisipasi bencana melalui langkah-langkah yang tepat, melakukan kembali pembangunan yang meliputi sarana dan prasarana jika ada yang rusak di karenakan berakibat terjadinya bencana hal itu wajib dilakukan oleh pemerintah daerah untuk menstabilakan perekonomian masyarakat. Karena setiap kondisi pasca bencana masyarakat yang akan mengalami kerugian.

Kegiatan Pencegahan bencana merupakan serangkaian kegiatan yang dilakukan sebagai upaya untuk menghilangkan dan/atau mengurangi ancaman bencana (UU Nomor 24 Tahun 2007 Pasal 1 ayat (6)). Pencegahan merupakan suatu upaya preventif dalam mengelola ancaman dan kerentanan dari risiko bencana yang tertuang dalam program-program di masyarakat di tingkat local maupun daerah di tingkat kabupaten untuk menghilangkan secara total ancaman dan kerentanan penyebab risiko bencana.

Kegiatan penanggulangan bencana adalah seluruh aspek kegiatan yang meliputi aspek perencanaan dan penanggulangan bencana pada sebelum terjadi, saat terjadi da sesudah terjadi bencana yang dirancang untuk memberikan kerangka bagi orang perorangan atau komunitas yang berisiko terkena bencana untuk menghindari risiko, mengendalikan risiko, mengurangi risiko, menanggulangi maupun memulihkan diri dari dampak bencana. Penyelenggaraaan penanggulangan bencana adalah serangkaian upaya yang meliputi penetapan kebijakan pembangunan yang berisiko timbulnya bencana, kegiatan pencegahan bencana, tanggap darurat, rehbilitasi dan rekonstruksi. Pemahaman tentang kegiatan penanggulangan bencana dapat disederhanakan dalam suatu siklus kegiatan.

Upaya yang dilakukan untuk mewaspadai bencana yang ada maka pihak Badan penanggulangan bencana melakukan integrasi dengan BMKG untuk melihat pergerakan dan pergantian cuaca yang akan terjadi di wilayah-wilayah Indonesia. Begitupun juga untuk Badan Peanggulangan bencana Daerah melakukan beberapa koordinasi dengan berbagai dinas untuk mewaspadai dan bentuk kesiapsiagaan yang akan terjadi, hal ini juga dilakukannya koordinasi dan integrasi dengan BMKG untuk melihat kondisi cuaca yang akan terjadi di daerah khususnya Kabupaten Sumenep. Seperti yang diketahui bahwa cuaca ektrim akhirakhir ini terjadi diwilayah Sumenep dengan terjadinya hujan deras yang mengguyur yang menyebabkan bencana banjir dikawasan sekitar kota. Cuaca ektrim yang terjadi ini dapat diwaspadai dengan dilakukannya beberapa pencegahan yang dilakukan dengan melibatkan masyarakat untuk ikut serta dalam pelatihan kewaspadaan dan kesiapsiagaan dalam menghadapi bencana.

Upaya penanggulangan bencana yang dilakukan oleh Badan 
Penanggulangan Bencana Daerah untuk mengantisipasi bencana yang sering terjadi di kawasan kota merupakan salah satu bentuk respon terhadap bencana yang akan terjadi seperti bencana hujan disertai angin yang menyebabkan banjir dan pohon tumbang, untuk mengantisipasi hal tersebut diadakannya informasi mengenai pentingnya menjaga lingkungan agar pada saat musim hujan berlangsung banjir tidak kembali menjadi masalah dimusim hujan. Pohon-pohon yang mulai tua, yang tidak sesuai dengan kelayakan maka akan dilakukan penebangan sehingga tidak terjadi pohon tumbang yang dapat menimbulkan korban.

Penyebab terjadinya banjir disebabkan banyak hal mulai dari kurangnya lahan serapan yang beralih fungsi menjadi perumahan atau perkebunan, rusaknya lingkungan akibat penebangan liar, pembuangan sampah sembarangan yang menyebabkan terhambatnya sistem aliran air dan penyebab-penyebab banjir lainnya. Sehingga sebagian besar wilayah Indonesia pasti menjadi langganan banjir, tidak terkecuali kebupaten sumenep. Beberapa tahun terakhir ini, pemerintah kabupaten Sumenep dihadapkan pada meluasnya banjir yang terjadi di daerah Sumenep dimana Badan Penanggulangan Bencana Daerah (BPBD) Kabupaten Sumenep merilis, bahwa memasuki musim angin dan hujan saat ini, wilayah Kabupaten Sumenep terdeteksi ada 21 titik rawan bencana. 21 titik rawan bencana alam tersebut tersebar di beberapa kecamatan, yakni diantaranya di kecamatan Kalianget, Pasongsongan dan Kecamatan Guluk-Guluk, Kecamatan Kota
Sumenep, Kecamatan Saronggi, Kecamatan dan Kecamatan Lenteng ${ }^{1}$.

Meluasnya titik rawan banjir yang ada di wilayah sumenep bukan saja menjadi masalah pemerintah daerah dan aparatur desa, tetapi bencana banjir merupakan masalah bersama yang mana perlu adanya komunikasi dan transparansi serta kebijakan yang tegas dari pemerintah, aparat desa dan masyarakat. Kebijakan yang ada tidak akan berjalan lancar tanpa adanya partisipasi masyarakat untuk mewujudkan mensukseskan kebijakan yang ada. Oleh sebab itu berbagai program yang dilakukan oleh Badan Penanggulangan Bencana (BPBD) supaya diarahkan untuk mencegah terjadinya bencana daerah dengan dilakukannya upaya peningkatan kesadaran, kewaspadaan dan kesiapsiagaan dalam menghadapi mencana di Kabupaten Sumenep.

\section{KAJIAN TEORI}

\section{Konsep Kebencanaan}

Bencana (disaster) adalah suatu gangguan serius terhadap keberfungsian suatu komunitas atau masyarakat yang mengakibatkan kerugian manusia, materi, ekonomi, atau lingkungan yang meluas yang melampaui kemampuan komunitas atau masyarakat yang terkena dampak untuk mengatasi dengan menggunakan sumberdaya mereka sendiri (ISDR, 2004). Undang-undang No 24 tahun 2007 tentang Penanggulangan Bencana mendefinisikan

\footnotetext{
1 Moh Rivai, "Ada 21 Titik Rawan Bencana di Sumenep", diakses si http://jatim.tribunnews.com/2018/11/20/ada-21titik-rawan-bencana-di-sumenep.
} 
bencana adalah peristiwa atau rangkaian peristiwa yang mengancam dan mengganggu kehidupan dan penghidupan masyarakat yang disebabkan, baik oleh faktor alam dan/atau faktor non-alam maupun faktor manusia sehingga mengakibatkan timbulnya korban jiwa manusia, kerusakan lingkungan, kerugian harta benda, dan dampak psikologis (Anonim, 2007).

\section{KONSEP KESIAGAAN}

\section{Deinisi Latihan Kesiapsiagaan}

Dalam pedoman ini, latihan kesiapsiagaan diartikan sebagai bentuk latihan koordinasi, komunikasi dan evakuasi dengan melibatkan seluruh pemangku kepentingan (pemerintah dan masyarakat umum). Seluruh pihak yang terlibat mensimulasikan situasi bencana sesungguhnya menggunakan skenario bencana yang dibuat mendekati atau sesuai kondisi nyata. Dengan mengacu pada deinisitersebut diatas, maka pedoman ini disusun untuk penyelenggaraan latihan yang melibatkan multipihak serta digunakan untuk membangun dan menyempurnakan system kesiapsiagaan sekaligus meningkatkan keterampilan dalam koordinasi serta pelaksanaan operasi penanggulangan bencana.

\section{Jenis-Jenis Latihan Kesiapsiagaan}

Latihan merupakan elemen yang sangat berperan penting dalam meningkatkan upaya kesiapsiagaan secara sistematis. Ada tiga tahapan latihan, yakni tahap pelatihan, tahap simulasi, dan tahap uji sistem.

Ketiganya memilik alur, yakni:

a. Pengertian bertahap dalam latihan kesiapsiagaan dilaksanakan mulai dari tahap awal analisis kebutuhan, perencanaan, persiapan dan pelaksanaan, serta monitoring dan evaluasi.

b. Berjenjang, berarti bahwa latihan dilakukan mulai dari tingkat kompleksitas paling dasar, yakni sosialisasi, hingga kompleksitas paling tinggi, yakni latihan terpadu/gladi lapang. Semua jenis latihan kesiapsiagaan dimaksudkan untuk meningkatkan kapasitas pemangku kepentingan, mulai dari peningkatkan pengetahuan, hingga sikap dan keterampilan dalam menjalankan fungsi dan tanggung jawab saat situasi darurat.

c. Berkelanjutan, dalam arti latihan kesiapsiagaan dilakukan secara terus menerus dan rutin. Kegiatan latihan kesiapsiagaan dapat dilakukan secara rutin, terutama di kota/ kabupaten risiko bencana yang tinggi, dan dilakukan minimal 1 tahun sekali guna mengurangi jumlah korban bencana.

Pada tahap latihan kesiapsiagaan, salah satu jenis latihan adalah evakuasi mandiri. Evakuasi mandiri adalah kemampuan dan tindakan individu/masyarakat secara mandiri, cepat, tepat, dan terarah berdasarkan langkah-langkah kerja dalam melakukan penyelamatan diri dari bencana. Latihan evakuasi mandiri adalah latihan untuk dilaksanakan oleh organisasi atau perusahaan, hotel, sekolah, desa, dan sebagainya dalam rangka merespon sistem peringatan dini bencana. Latihan kesiapsiagaan biasanya dilakukan pada tingkat komunitas, seperti organisasi perusahaan, hotel, sekolah, desa, dan lain sebagainya

\section{Upaya Penting Kesiapsiagaan}

a. Memahami bahaya disekitar anda 
b. Memahami sistem peringatan dini (mengetahui rute evaluasi dan pengungsian)

c. Memiliki keterampilan untuk mengevaluasi situasi secara cepat dan mengambil inisiatif tindakan

d. Memiliki rencana antisipasi bencana dan mempratekkan dengan latihan

e. Mengurangi dampak bahaya melalui latihan

f. Melibatkan diri dalam partisipasi dalam pelatihan

(Sumber : Buku Saku 3T menghadapi bencana oleh BNPB)

\section{METODE PENELITIAN}

Pada penelitian ini peneliti dalam mengkaji masalah menggunakan metode penelitian kualitatif untuk menentukan cara mencari, mengumpulkan, mengolah dan menganalisis data hasil penelitian. Metode penelitian kualitatif dapat digunakan untuk memahami interaksi sosial, dimana menurut Moleong (2007:6) adalah penelitian yang bermaksud untuk memahami fenomena tentang apa yang dialami oleh subjek penelitian misalnya perilaku, persepsi, motivasi,tindakan, dll., secara holistik, dan dengan cara deskripsi dalam bentuk kata-kata dan bahasa, pada suatu konteks khusus yang alamiah dan dengan memanfaatkan berbagai metode alamiah $^{2}$. Objek penelitian adalah obyek yang dijadikan penelitian atau yang menjadi titik perhatian suatu penelitian, sehingga dalam hal ini Badan Penanggulangan Bencana Daerah (BPBD) sebagai sasaran penelitian.

\footnotetext{
${ }^{2}$ Moleong, Lexy J. (2007) Metodologi Penelitian Kualitatif, Penerbit PT Remaja Rosdakarya Offset, Bandung, p.6
}

Teknik analisa data, yang dilakukan peneliti (Bognan \& Biklen (1982) sebagaimana dikutip Moleong (2007:248), yaitu pertama, reduksi data yang merupakan proses pemilihan, pemusatan, perhatian pada penyederhanaan data dari semua data yang diperoleh. Kedua, penyajian data dilakukan dengan proses pengorganisasian untuk memudahkan data dianalisis dan disimpulkan. Ketiga, penarikan kesimpulan, yaitu membuat pernyataan atau kesimpulan secara bulat tentang suatu permasalahan yang diteliti dalam bahasa yang deskriptif dan bersifat interpretatif.

\section{HASIL DAN PEMBAHASAN}

Pada dasarnya bencana alam yang terjadi disekitar kita tidak dapat diprediksi secara pasti oleh manusia akan tetapi sebagai bentuk usaha untuk mencegah bencana yang akan terjadi merupakan salah satu upaya yang dapat dilakukan untuk memperkecil dampak dari adanya bencana yang akan datang. Bencana dapat dibedakan menjadi tiga yaitu bencana alam, non alam dan sosial, biasanya bencana alam tidak dapat diprediksi karena hal ini merupakan sifat alami bumi sedangkan untuk bencana non alam dan sosial disebabkan karena perilaku buruk masyarakat yang menyebkan terjadinya bencana. Berikut bencana yang terjadi di Kabupaten Sumenep. 
Tabel 4.1

Bencana Alam, Non Alam Dan Sosial

Tahun 2018

\begin{tabular}{|l|l|l|l|}
\hline \hline No & Kejadian Bencana & $\begin{array}{l}\text { Jumlah } \\
\text { Korban }\end{array}$ & $\begin{array}{l}\text { Frekeunsi } \\
\text { Bencana }\end{array}$ \\
\hline 1. & Angin Puting Beliung & 195 & 12 \\
\hline 2. & Angin Kencang & 91 & 36 \\
\hline 3. & Hujan Deras disertai angin & 185 & 81 \\
\hline 4. & Hujan Deras & 9 & 6 \\
\hline 5. & Kebakaran & 40 & 32 \\
\hline 6. & Banjir & 4 & 1 \\
\hline 7. & Longsor & 2 & 2 \\
\hline 8. & Gempa & 730 & 3 \\
\hline 9. & Sambar Petir & 13 & 6 \\
\hline 10. & Kejadian Laut & 35 & 9 \\
\hline 11. & Sosial & 11 & 5 \\
\hline & Jumlah & $\mathbf{1 3 1 7}$ & $\mathbf{1 9 3}$ \\
\hline
\end{tabular}

Sumber : BPBD Kab. Sumenep, 2018

Bentuk upaya yang dilakukan untuk memberikan kesadaran, kewaspadaan dan kesiapsiagaan kepada masyarakat dengan memberikan informasi dan pelatihan untuk melatih agar masyarakat mampu untuk mengelola bencana yang akan terjadi sehingga dengan upaya yang dilakukan ini akan meminimalkan bentuk kerugian atau korban yang akan dialami pada saat bencana terjadi. Seperti halnya yang terjadi di Kabupaten Sumenep dalam upaya meningkatkan kesadaran, kewaspadaan, dan kesiapsiagaan masyarakat dalam menghadapi bencana yang akan terjadi seperti yang diketahui akhir-akhir ini cuaca ekstrim menimpa kabupaten
Sumenep dengan intens hujan yang cukup deras.

Diperlukan berbagai upaya untuk menghadapi bencana yang akan terjadi di Kabupaten Sumenep dengan menetapkan berbagai program kebencanaan yang dilakukan oleh Badan Penanggulangan Bencana Daerah selaku lokus dalam penelitian ini. Dalam penelitian ini juga untuk mengetahui beberapa faktor penghambat dari dilakukannya upaya peningkatan kesadaran, kewaspadaan dan kesiapsiagaan masyarakat dalam menghadapi bencana yang tidak terduga. penelitian dilakukan dengan menggunakan pendekatan interview dan melakukan 
observasi di lokasi peneliatian yakni di Badan Penanggulangan Bencana Daerah Kabupaten Sumenep. Hasil interview dan observasi di analisa diantaranya, yaitu:

\subsubsection{Upaya Peningkatan Kesadaran, Kewaspadaan dan Kesiapsiagaan}

Bencana alam pada dasarnya tidak dapat dicegah secara pasti karena bencana yang bersifat alam merupakan bencana yang tidak dapat diprediksi, akan tetapi sebagai bentuk usaha untuk memberikan keselamatan kepada masyarakat BMKG ikut memberikan peringatan mengenai bencana yang akan terjadi yang dilihat berdarkan ciri alam yang mulai menunjukkan akan terjadinya bencana. Oleh sebab itu dalam hal ini Badan Penanggulangan Bencana Daerah merespon berbagai bencana yang terjadi dengan beberapa kegiatan yang dilakukan pada saat sebelum bencana sebagai antisipasi ataupun sesudah bencana sebagai tanggap aksi. Kegiatan yang dilakukan kepada masyarakat pada saat prabencana yaitu memberikan sosialisasi dan pemberitahuan dini mengenai kewaspadaan masyarakat terhadap bencana yang akan terjadi sehingga dengan adanya peringatan dini akan memberikan tindakan siapsiaga dalam menghadapi bencana yang akan terjadi.

Kegiatan Pencegahan bencana adalah serangkaian kegiatan yang dilakukan sebagai upaya untuk menghilangkan dan/atau mengurangi ancaman bencana (UU No. 24 Tahun 2007 Pasal 1 ayat (6) Pencegahan merupakan suatu upaya preventif dalam mengelola ancaman dan kerentanan dari risiko bencana yang tertuang dalam programprogram di masyarakat di tingkat local maupun daerah di tingkat kabupaten untuk menghilangkan secara total ancaman dan kerentanan penyebab risiko bencana.

UU No, 24 Tahun 2007 menjelaskan mengenai kegiatan pencegahan yang dilakukan sebelum terjadinya bencana yang ditungkan dalam program yang melibatkan masyarakat dalam hal ini tentunya program yang akan dijalankan merupakan tugas dan tanggung jawab dari Badan Penanggulangan Bencana baik itu Nasional maupun Daerah yang mengharapkan program yang diberikan akan memiliki dampak untuk meningkatkan kesadaran, kewaspadaan dan kesiapsiagaan masyarakat dalam menghadapi bencana sehingga dengan hal ini maka jumlah korban akan minim. Dalam meningkatkan kesadaran masyarakat untuk menghadapi bencana yang akan terjadi dilakukan dengan memberikan sosialisasi dan pelatihan khusus untuk menghadapi bencana maka hal ini merupakan upaya preventif yang dilakukan oleh Badan Penanggulangan Bencana Daerah untuk mengurangi ancaman yang terjadi.

Tertuang dalam buku saku 3T BNBP panduan dalam menghadapi bencana yang diterbitkan pada tahun 2017 menjelaskan mengenai upaya penting dalam memberikan kesadaran, kewaspadaan dan kesiapsiagaan kepada masyarakat dengan dilakukannya beberapa hal berikut ini:

a. Memahami bahaya disekitar anda

b. Memahami sistem peringatan dini (mengetahui rute evaluasi dan pengungsian)

c. Memiliki keterampilan untuk mengevaluasi situasi secara cepat dan mengambil inisiatif tindakan 
d. Memiliki rencana antisipasi bencana dan mempratekkan dengan latihan

e. Mengurangi dampak bahaya melalui latihan

f. Melibatkan diri dalam partisipasi dalam pelatihan

Rangkaian upaya yang dilakukan dengan tahapan diatas merupakan bentuk sosialisasi dan pelatihan yang dilakukan oleh Badan Penanggulangan Bencana Daerah maupun Nasional, rangkaian tahapan diatas merupakan bentuk preventif yang dilakukan oleh BPBD untuk menghadapi bencana yang akan terjadi diwilayah yang telah ditentukan sebagai wilayah yang rawan akan bencana.

Hasil penelitian yang dilakukan di Badan Penanggulangan Bencana Daerah mengenai upaya yang dilakukan pra bencana sebagai bentuk preventif mengurangi ancaman bencana yang akan terjadi, upaya yang dilakukan tersebut dapat dilihat dari beberapa wawancara yang dilakukan di Badan Penanggulangan Bencana Daerah

Hasil interview dengan Drs. $\mathrm{H}$. Sutrisno, M.Si Kabid Pencegahan dan Kesiapsiagaan Kabupaten Sumenep, mengatakan bahwa

"sebagai bentuk upaya yang dilakukan BPBD dalam merespon bencana yang akan terjadi dengan melakukan sosialisasi dan pelatihan, akan tetapi bentuk pelatihan ini memang untuk desa yang sudah kami tetapkan sebagai lokasi sosialisasi atau kami sebut dengan DESTANA (Desa Tanggap Bencana), jadi Desa-desa yang kami golongkan sebagai desa rawan bencana kami lakukan upaya preventif untuk mencegah apabila bencana yang akan terjadi sedikit kemungkinan kerugian dalam hal ini kami memandirikan masyarakat untuk bisa membantu diri sendiri dan orang lain untuk upaya penyelamatan karena kami tidak beroperasi 24 jam yang selalu ada untuk masyarakat. (Rabu, 15 Mei 2019 pukul 10.00 di kantor BPBD Kab. Sumenep)

Selaras dengan yang diungkapkan oleh Bapak H. Sutrisno, Interview dengan Hj. Suswartini, Kasi Pencegahan BPBD Kabupaten Sumenep, juga mengatakan bahwa upaya yang dilakukan oleh Badan Penanggulangan Bencana Daerah berupa sosialisasi dan pelatihan kebencanaan.

"dalam memberikan sosialisasi untuk masyarakat supaya mereka sadar akan ancaman bencana dengan memberikan sosialisasi sehari misalkan ini tidak bisa jadi kita memang memiliki program pembimbingan dimana dalam program ini masyarakat atau desa yang sudah kami tentukan dalam DESTANA akan kami bimbing secara berkelanjutan tidak hanya sosilisasi kami juga melakukan pelatihan bagaimana untuk menyelamatkan diri, jalur evakuasi dan tempat posko yang aman dan sebagainya jadi

memang hal ini sudah dilakukan oleh BPBD” (Rabu, 15 Mei 2019 pukul 10.00 di kantor BPBD Kab. Sumenep)

Selanjutnya Interview dengan RM. Faizal Rizal, S.Hut, M.Si, Kasi Kesiapsiagaan BPBD Kabupaten Sumenep, mengatakan bahwa 
"kalau upaya yang dilakukan pra bencana memang kita mempunyai preventif program untuk mendampingi dan membimbing masyarakat supaya sigap akan bencana akan tetapi tidak seluruh se kabupaten sumenep kami adakan sosialisasi dan saya kira juga itu tidak akan efektif, jadi kami menggolongkan Desa-desa yang rawan bencana biasanya kami sebut dengan DESTANA, yang tergolong dalam kelompok ini yaitu Desa Kertasada disana kan rawan banjir rob, puting beliung jadi kami masukkan kedalam daftar Destana, selain itu juga ada Batuputih, Sindir (Lenteng), Batang-batang Daya itu tergolong dalam Destana kami melakukan sosialisasi dan pelatihan simulasi bencana sehingga dengan dilakukan upaya ini maka mereka memiliki kesadaran, kewaspadaan dan siap siaga dalam menghadapi bencana yang ada" (Rabu, 15 Mei 2019 pukul 10.00 di kantor BPBD Kab. Sumenep)

Dalam wawancara tersebut menunjukkan bahwa upaya yang dilakukan oleh BPBD dalam menghadapi pra bencana dilakukan dengan sosialisasi yang berkelanjutan dimana program preventif yang dilakukan dianggap lebih efektif untuk memberikan sosialisasi kepada masyarakat. untuk memberikan kesadaran kepada masyarakat khususnya masyarakat awam yang mereka kadang kala sulit untuk berpartisipasi dalam kegiatan yang dilakukan BPBD hal ini juga yang menjadi kendala dalam dilakukannya sosialisasi sehingga dengan dilakukannya sosialisasi sekali atau dua kali itu tidak akan memiliki efek apapun untuk masyarakat oleh sebab itu harus dilakukan pendampingan dan sosialisasi yang berkelanjutan untuk masyarakat.

Desa yang tergolong dalam DESTANA (Desa Tanggap Bencana) akan dilakukan sosialiasai yang berkelanjutan dengan disertakan praktek dalam simulasi penyelamatan, praktek agar tidak panik dan tetap berfikir secara positif, serta masyarakat diajari bagaimana untuk mengambil inisiatif tindakan secara cepat untuk penyelamatan, jadi upaya ini akan terus berkelanjutan sampai mereka mandiri dalam mengelola situasi pra bencana, akan tetapi bencana yang sering terjadi kadang kala berada diluar kawasan yang tidak termasuk kedalam DESTANA hal ini tentunya akan dibutuhkan peran BPBD pula sebagai badan penanggulangan bencana, akan tetapi diuangkapkan bahwa tidak semua diadakan sosialisasi maka yang dilakukan BPBD yang lain untuk masalah seperti itu yaitu dengan memberikan peringatan bahwa daearah ini akan mengalami cuaca buruk dan sebagainya sehingga masyarakat lebih waspada.

Seperti diketahui bahwa datangnya bencana tidak dapat diprediksi secara pasti akan tetapi hal yang perlu dilakukan dengan datangnya bencana setidaknya dapat mengurangi ancaman yang ada seperti banjir yang sering terjadi dikawasan kota maka butuh penanganann khsusus untuk menghadapi bencana tersebut.

Hasil interview dengan R. Muh. Bahaudin, Sh, MH Sekretaris BPBD Kabupaten Sumenep, mengenai bencana alam yang terjadi secara tiba-tiba

"BPBD tidak tinggal diam dalam mengatasi bencana yang terjadi di Kabupaten Sumenep ini, pihak 


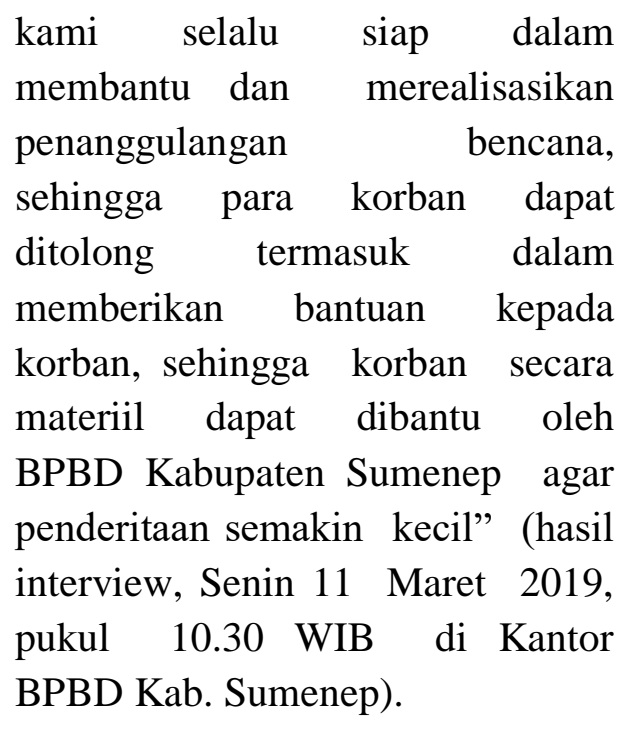

Hasil interview dengan Drs. $\mathrm{H}$. Sutrisno, M.Si Kabid Pencegahan dan Kesiapsiagaan Kabupaten Sumenep, mengatakan bahwa

"BPBD Kabupaten Sumenep
dengan upaya agresinya yang
ditunjukkan kepada para korban
dalam menolongnya, dimana
setiap kejadian alam, non, dan
sosial meamndang siapapun"
(hasil interview hari Selasa, 12
Maret 2019, pukul 10.15 WIB di
Kantor BPBD Kab. Sumenep)

Keadaan demikian menunjukkan adanya respon yang agresif dalam menolong kejadian bencana bagi korban yang terkena dampaknya, sehingga para korban dapat teratasi secara cepat.

Interview dengan Hj. Suswartini, Kasi Pencegahan BPBD Kabupaten Sumenep, mengatakan bahwa

\footnotetext{
"BPBD senantiasa respon dalam menolong bencana di masyarakat dan selalu siap dalam kesiapsiagaannya membantu masyarakat untuk bisa bangkit dari terkena bencana, sedangkan untuk
}

bencana banjir dan sebagainya itu bukan hanya respon kami yang dibutuhkan tapi kami koordinasi dengan OPD lain untuk ikut serta dalam mengurangi banjir di Kabupaten Sumenep" (hasil interview hari Rabu, 13 Maret 2019, pukul 10.05 WIB di Kantor BPBD Kab. Sumenep)

Interview dengan RM. Faizal Rizal, S.Hut, M.Si, Kasi Kesiapsiagaan BPBD Kabupaten Sumenep, mengatakan bahwa

"BPBD selalu agresif dalam membantu dan menangani korban dalam penanganannya bersama masyarakat serta dibantu oleh petugas damkar dan lainnya yang ada di BPBD, sehingga penanganan bencana dan korban dapat teratasi secara cepat" (hasil interview hari Rabu, 13 Maret 2019, pukul 11.15 WIB di Kantor BPBD Kab. Sumenep)

Interview dengan R. Muh. Bahauddin, SH, MH, Sekretaris BPBD Kabupaten Sumenep, mengatakan bahwa

"BPBD Kabupaten Sumenep telah mampu memberikn upaya dalam penanganan bencana dalam bentuk penanganan yang telah ditangani secara tepat dan singkat pada saat itu juga dan dibantu dalam menangani bencana dengan penuh kehati-hatian sehingga korban merasa dibantu oleh pihak BPBD termasuk bantuan stimulan atas pergantian untuk memperbaiki yang rusak, dan keberadaan korban merasa senang mendapat bantuan dari pemerintah" (hasil interview hari 
Senin, 18 Maret 2019, pukul

Kabupaten Sumenep)

10.45 WIB di Kantor BPBD

Tabel 4.2

Bantuan Stimulan Yang Diberikan

\begin{tabular}{|c|c|c|c|}
\hline No & Kejadian Bencana & $\begin{array}{l}\text { Taksiran } \\
\text { Kerugian }\end{array}$ & $\begin{array}{l}\text { Bantuan } \\
\text { stimulan }\end{array}$ \\
\hline 1. & Angin Puting Beliung & 776.950 .000 & 119.100 .000 \\
\hline 2. & Angin Kencang & 1.059 .500 .000 & 130.500 .000 \\
\hline 3. & Hujan Deras disertai angin & 1.973 .000 .000 & 253.000 .000 \\
\hline 4. & Hujan Deras & 143.500 .000 & 21.000 .000 \\
\hline 5. & Kebakaran & 902.000 .000 & 81.500 .000 \\
\hline 6. & Banjir & 21.500 .000 & 4.000 .000 \\
\hline 7. & Longsor & 37.500 .000 & 6.500 .000 \\
\hline 8. & Gempa & 6.869 .000 .000 & 296.500 .000 \\
\hline 9. & Sambar Petir & 18.500 .000 & 12.500 .000 \\
\hline 10. & Kejadian Laut & 26.500 .000 & 15.250 .000 \\
\hline \multirow[t]{2}{*}{11.} & Sosial & 0 & 25.500 .000 \\
\hline & Jumlah & 11.827.950.000 & 965.350 .000 \\
\hline
\end{tabular}

Sumber : BPBD Kab. Sumenep, 2018

Interview dengan $\mathrm{H}$. Moh.

Kadar, S.Sos, M.Si, Kepala Bidang

Kedaruratan dan Logistik, BPBD

Kabupaten Sumenep, mengatakan bahwa

"BPBD selalu melakukan upaya konservatif dalam menagani korban termasuk pemulihan korban dengan memberikan bantuan stimulan sehingga korban merasa tertangani secara tepat, dan korban merasa terkuarangi beban penderitaannya dengan dibantu dan diberikan stimulan kepadanya, dan kegiatan ini telah menjadi program prioritas dalam menangani bencana alam" (hasil interview hari Selasa 19 Maret 2019, pukul 15.15 WIB di Kantor BPBD Kabupaten Sumenep)

Hasil interview dengan masyarakat di lapangan yang dilakukan peneliti menunjukkan upaya konservatif yang dilakukan BPBD Kabupaten Sumenep kepada korban bencana alan dan 
bencana non alam dan sosial, sebagai berikut :

"BPBD Kabupaten Sumenep
dalam menolong korban dan
membantu korban tidak
hanya secara fisik, namun
juga memberikan bantuan
stimulan untuk biaya
mengganti kerusakan yang
telah dideritanya, maupun
secara tim secara langsung
turun ke lapangan pada saat
kejadian dan korban akan
merasa senang, karena pada
saat kejadian didampingi
oleh BPBD Kabupaten
Sumenep, secara psikis
korban dapat terkurangi
karena diberikan pemahaman
mental dalam menghadapi
kejadian yang diluar
dugaan".

Interview dengan $\mathrm{H}$. Moh. Kadar, S.Sos, M.Si, Kepala Bidang Kedaruratan dan Logistik, BPBD Kabupaten Sumenep, mengatakan bahwa

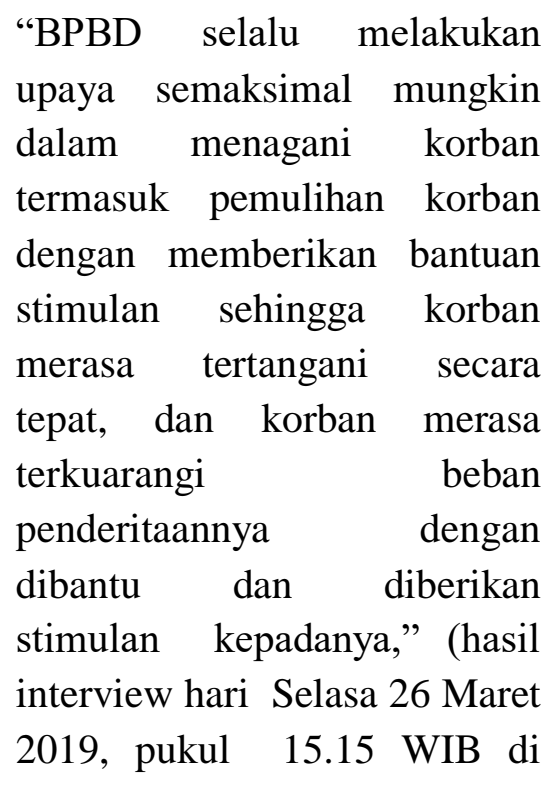

Kantor BPBD Kabupaten Sumenep)

\section{KESIMPULAN DAN SARAN}

\section{Kesimpulan}

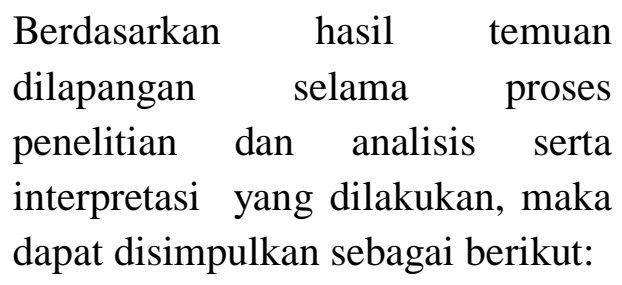

1. Upaya peningkatan kesadaran, kewaspadaan dan kesiapsiagaan yang dilakukan oleh BPBD terhadap DESTANA (Desa Tangguh Bencana) telah berupaya untuk meningkatkan kesadaran dan keterampilan masyarakat dalam bentuk sosialisasi dan pelatihan secara berkelanjutan dengan melakukan berbagai pelatihan simulasi penyelamatan sedangkan Situasi bencana yang terjadi diluar cakupan DESTANA, BPBD telah memberikan pelayanan dalam penyelamatan bencana dengan pemberian anggaran terhadap korban.

\section{Saran}

1. Diharapkan dalam pencegahan bencana yang dilakukan oleh BPBD juga didukung oleh Organisasi Pemerintah Daerah sehingga dengan adanya koordinasi antar OPD dapat meminimalkan bencana. 
2. Diharapkan dengan adanya informasi, sosilalisasi dan pelatihan oleh BPBD Kabupaten Sumenep dapat semakin menggerakkan kewaspadaan dan kesiapsiagaan masyarakat dan mereka pro aktif dalam membantu upaya penanggulan bencana yang dilakukan OPD terkait.

\section{DAFTAR PUSTAKA}

Arikunto, S., Prosedur penelitian : Suatu Pendekatan Praktik. (Edisi Revisi). Jakarta : Rineka Cipta, 2010.

\section{Astiapilia,"Kurangnya Pemerataan Pendidikan Indonesia", diakses di http://www.kompasiana.com/astia prilia/kurangnya-pemerataan- pendidikan- indonesia_54f5fe87a333116a7d8 b477c, 14 Agustus 2017}

Ben Fauzi Ramadhan,"Gambaran Persepsi Literatur", di akses di $\underline{\text { lib.ui.ac.id/file?file }=\text { digital/12541 }}$ 6-S-5609-Gambaran\%20persepiLiteratur.pdf, 21 Agustus 2017.

Buku saku 3 T BNPB dalam menghadapi bencana tahun 2017

Buku BNPB Panduan Latihan Kesiapsiagaan tahun 2017
H.A.R Tilaar (2009). Kekuasaan dan Pendidikan: Manajemen Pendidikan Nasional dalam Pusaran Kekuasaan. Jakarta: Rineka Cipta.

Jalal, Fasli dan Dedi Supriadi, 2001, Reformasi Pendidikan Dalam Konteks Otonomi Daerah, Yogyakarta: Adicita Karya Nusa

Koentjaraningrat, Metode-Metode Penelitian Masyarakat, Edisi Ketiga, Jakarta: Gramedia, 1993.

Moleong, Lexy J., Metodologi Penelitian Kualitatif, Bandung : PT Remaja Rosdakarya, 2007.

Notoatmodjo, Soekidjo a, Ilmu Kesehatan Masyarakat. Jakarta: Rineka Cipta, 1997.

Phillip Kotler, Marketing Management Analysis, Planning, Implementation\& Control. Prentice Hall Int, 1995.

Siagian, Sondang P, Teori Motivasi dan Aplikasinya. Bina Aksara, Jakarta, 1989.

Soekidjo Notoatmodjo, Pendidikan Dan Perilaku Kesehatan, Jakarta:Rineka Cipta, 2003.

Sundariningrum.2001.Klasifikasi Partisipasi.Jakarta: Grasindo. 